\title{
Regulation of KIF2A by Antitumor miR-451a Inhibits Cancer Cell Aggressiveness Features in Lung Squamous Cell Carcinoma
}

\author{
Akifumi Uchida ${ }^{1}{ }^{(}$, Naohiko Seki ${ }^{2, *}{ }^{\mathbb{D}}$, Keiko Mizuno $^{1}$, Yasutaka Yamada ${ }^{2}{ }^{(D}$, \\ Shunsuke Misono ${ }^{1}{ }^{10}$, Hiroki Sanada ${ }^{1}$, Naoko Kikkawa ${ }^{2}$, Tomohiro Kumamoto ${ }^{1}$, \\ Takayuki Suetsugu ${ }^{1}$ and Hiromasa Inoue ${ }^{1}$ \\ 1 Department of Pulmonary Medicine, Graduate School of Medical and Dental Sciences, Kagoshima \\ University, Kagoshima 890-8520, Japan; akiuchi@m3.kufm.kagoshima-u.ac.jp (A.U.); \\ keim@m.kufm.kagoshima-u.ac.jp (K.M.); k8574402@kadai.jp (S.M.); k8173956@kadai.jp (H.S.); \\ kuma@m2.kufm.kagoshima-u.ac.jp (T.K.); taka3741@m2.kufm.kagoshima-u.ac.jp (T.S.); \\ inoue-pulm@umin.net (H.I.) \\ 2 Department of Functional Genomics, Graduate School of Medicine, Chiba University, Chuo-ku, \\ Chiba 260-8670, Japan; yasutaka1205@olive.plala.or.jp (Y.Y.); naoko-k@hospital.chiba-u.jp (N.K.) \\ * Correspondence: naoseki@faculty.chiba-u.jp; Tel.: +81-43-226-2971
}

Received: 27 January 2019; Accepted: 18 February 2019; Published: 22 February 2019

\begin{abstract}
In the human genome, $m i R-451 a$ is encoded close to the miR-144 on chromosome region 17q11.2. Our previous study showed that both strands of pre-miR-144 acted as antitumor miRNAs and were involved in lung squamous cell carcinoma (LUSQ) pathogenesis. Here, we aimed to investigate the functional significance of $m i R-451 a$ and to identify its targeting of oncogenic genes in LUSQ cells. Downregulation of miR-451a was confirmed in LUSQ clinical specimens, and low expression of $m i R-451 a$ was significantly associated with poor prognosis of LUSQ patients (overall survival: $p=0.035$, disease-free survival: $p=0.029$ ). Additionally, we showed that ectopic expression of $m i R-451 a$ significantly blocked cancer cell aggressiveness. In total, 15 putative oncogenic genes were shown to be regulated by miR-451a in LUSQ cells. Among these targets, high kinesin family member 2A (KIF2A) expression was significantly associated with poor prognosis (overall survival: $p=0.043$, disease-free survival: $p=0.028$ ). Multivariate analysis showed that KIF2A expression was an independent prognostic factor in patients with LUSQ (hazard ratio $=1.493, p=0.034$ ). Aberrant KIF2A expression promoted the malignant transformation of this disease. Analytic strategies based on antitumor miRNAs and their target oncogenes are effective tools for identification of novel molecular pathogenesis of LUSQ.
\end{abstract}

Keywords: microRNA; miR-451a; KIF2A; lung squamous cell carcinoma; antitumor

\section{Introduction}

Lung cancer is the most common cause of cancer-related death worldwide, accounting for more than 1.7 million deaths each year [1]. The most common type of lung cancer is non-small cell lung cancer (NSCLC), which can be divided into several subtypes, including squamous cell carcinoma (LUSQ), adenocarcinoma (LUAD), and large cell carcinoma [2]. Patients with LUAD show improved survival rates following treatment with epidermal growth factor receptor tyrosine kinase inhibitors, anaplastic lymphoma kinase tyrosine kinase inhibitors, and immune checkpoint inhibitors [3-6].

LUSQ remains a common cancer among NSCLCs, and over 400,000 people worldwide are diagnosed with LUSQ each year [7]. The majority of patients with LUSQ have a history of heavy smoking, highlighting tobacco-related carcinogenesis as a clear causative factor of LUSQ. 
Many mutations accumulate in LUSQ cells owing to the influence of heavy smoking over many years [7]. However, no universal therapeutic targets have currently been found for LUSQ, despite many studies. In contrast to treatment for LUAD, conventional platinum-based chemotherapy has still been performed for inoperable cases of LUSQ in the past two decades [7].

Furthermore, given the malignant nature of LUSQ, it has high invasive and metastatic potential. Distant metastases at the time of presentation of LUSQ are a frequent clinical problem. Many patients with LUSQ present with metastatic disease at the time of diagnosis [8]. For these reasons, continued research, applying advanced genomic-based approaches, is indispensable for identification of novel biomarkers for earlier detection and for development of effective targeted molecular therapies for LUSQ.

MicroRNAs (miRNAs) are small noncoding RNAs (19-24 nucleotides in length) that modulate the expression of many genes by blocking translation or degrading mRNAs in a sequence-dependent manner [9]. Notably, one miRNA can regulate the expression of many protein-coding and noncoding RNA transcripts [10]. Thus, aberrantly expressed miRNAs can disrupt normal cell function, thereby supporting cancer pathogenesis [11]. Many studies have shown that aberrantly expressed miRNAs are involved in the pathogenesis of many diseases, including cancer [12-14].

It is possible to explore oncogenic networks in LUSQ cells controlled by oncogenic or antitumor miRNAs using advanced genomic approaches. We have sequentially identified antitumor miRNAs and their targeted oncogenic genes and pathways in LUSQ cells, e.g., miR-145-5p/-3p (targeting oncogene: MTDH), miR-150-5p (MMP14), miR-29-family (LOXL2), and miR-218 (TPD52) [15-18]. Recently, we revealed that both strands of miR-144 (miR-144-5p (the passenger strand) and miR-144-3p (the guide strand)) act as antitumor miRNAs and that these miRNAs significantly block malignant abilities through coordinated targeting of NCS1 [19]. Furthermore, analysis of the expression profiles of miR-144-5p, miR-144-3p, and NCS1 can be used to help predict prognosis in patients with LUSQ [19]. Researchers are now recognizing miRNA passenger strands as active players in cancer pathogenesis.

In this study, we focused on miR-451a because it has been shown to form miRNA clusters (miR-144-5p/miR-144-3p/miR-451a) located in the human chromosome 17q11.2 region. Downregulation of miR-451a was confirmed in LUSQ clinical specimens, and low expression of miR-451a was found to be significantly associated with poor prognosis in patients with LUSQ (overall survival (OS): $p=0.035$, disease-free survival (DFS): $p=0.029$ ). We investigated the functional significance of miR-451a in LUSQ cells and identified the oncogenic genes regulated by miR-451a in LUSQ pathogenesis. Moreover, kinesin family member 2A (KIF2A) was directly controlled by miR-451a and its expression was closely associated with LUSQ pathogenesis. Analytic strategies based on antitumor miRNAs and their target oncogenes are effective tools for identification of novel molecular pathogenesis of LUSQ.

\section{Results}

\subsection{Downregulation of miR-451a in LUSQ Clinical Specimens and Its Clinical Significance}

In total, 50 clinical specimens (30 LUSQ tissues and 20 noncancerous lung tissues) were obtained from patients who underwent thoracic surgery at Kagoshima University Hospital. The characteristics of the patients are shown in Table 1 . The expression level of miR-451a was significantly downregulated in LUSQ tissues as compared with those in noncancerous tissues $(p<0.001$, Figure 1A). In two LUSQ cell lines, EBC-1 and SK-MES-1, the expression levels of miR-451a were markedly low (Figure 1A).

To investigate the clinical significance of $m i R-451 a$ in LUSQ, we applied The Cancer Genome Atlas (TCGA) database analyses. Patients with low expression of miR-451a showed significantly poor prognosis compared with patients with high expression of miR-451a (5-year OS: $p=0.035$ and 5 -year DFS: $p=0.029$, Figure 1B). Furthermore, in LUSQ patients with adjusting clinical stage and age distribution, low expression of miR-451a also predicted poor prognosis compared with high expression of miR-451a (5-year OS: $p=0.026$ and 5-year DFS: $p=0.024$, Figure S1). 
A

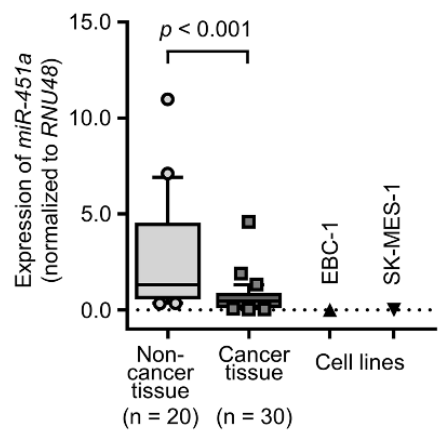

C

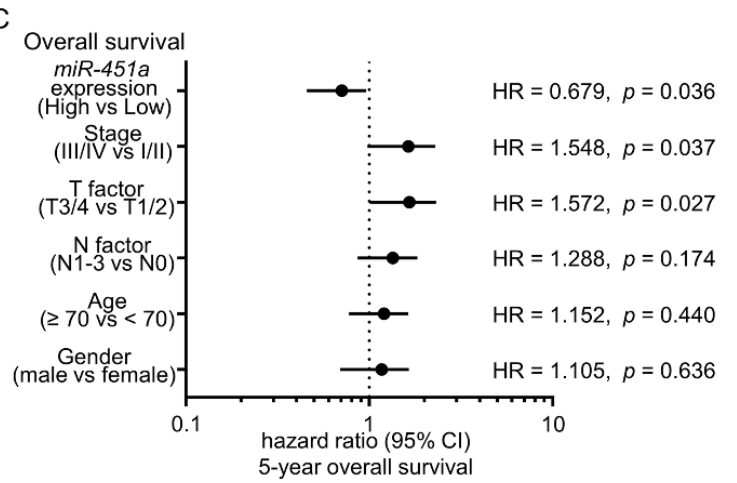

miR-451a expression
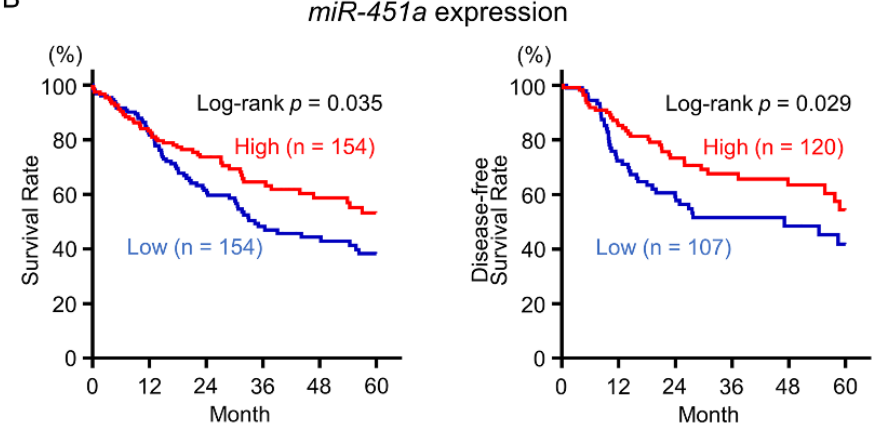

D

Overall survival

Multivariate cox proportional hazards regression analysis

\begin{tabular}{|c|c|c|c|}
\hline & hazard ratio & $95 \% \mathrm{Cl}$ & $p$-value \\
\hline miR-451a & 0.667 & $0.463-0.960$ & 0.029 \\
\hline Stage & - & - & 0.318 \\
\hline T factor & 1.618 & $1.082-2.421$ & 0.019 \\
\hline
\end{tabular}

Figure 1. Expression levels of miR-451a in lung squamous cell carcinoma (LUSQ) clinical specimens and association with prognosis in patients with LUSQ. (A) $m i R-451 a$ expression levels in clinical specimens and cell lines (EBC-1 and SK-MES-1). (B) Kaplan-Meier curve of 5-year overall survival and 5-year disease-free survival according to miR-451a expression among patients with LUSQ in The Cancer Genome Atlas (TCGA) database ( $p=0.035$ and $p=0.029$, respectively). Patients were divided into high (red) and low (blue) expression groups. (C,D) Forest plot of univariate Cox proportional hazards regression analysis and multivariate Cox proportional hazards regression analysis of 5-year overall survival for miR-451a expression using TCGA database.

Table 1. Characteristics of lung cancer and noncancerous cases.

\begin{tabular}{ccc}
\hline \multicolumn{3}{c}{ A. Characteristics of Lung Cancer Cases } \\
\hline Total number & $\mathbf{3 0}$ & \\
\hline Median age (range) & $71(50-88)$ & $(\%)$ \\
Sex & $\mathrm{n}$ & $(96.7)$ \\
Male & 29 & $(3.3)$ \\
Female & 1 & $(16.7)$ \\
\hline Pathological stage & & $(30.0)$ \\
\hline IA & 5 & $(6.7)$ \\
IB & 9 & $(20.0)$ \\
IIA & 2 & $(3.3)$ \\
IIB & 6 & \\
IIIA & 7 & \\
IIIB & 1 & \\
B. Characteristics of noncancerous tissues \\
\hline Total number & 20 & \\
Median age (range) & 70.5 & $(50-88)$ \\
Sex & $\mathrm{n}$ & \\
Male & 20 & \\
Female & 0 &
\end{tabular}

The pathological stage of lung cancer was classified according to Lung Cancer TNM classification, 7th Edition. 
Multivariate analysis showed that low expression of $m i R-451 a$ was an independent prognostic factor in patients with LUSQ (hazard ratio $=0.667, p=0.029$, Figure 1D). By analyzing combination $m i R-451 a, m i R-144-3 p$ and miR-144-5p expression, combination both high expression of miR-451a and miR-144-5 $p$ predicted additive poor prognosis compared with high expression miR-451a alone or miR-144-5 $p$ alone (Figure S2).

In addition, TCGA database analyses showed that low expression of miR-451a was associated with poor prognosis in patients with renal papillary cell carcinoma and renal clear cell carcinoma (Figure S3).

\subsection{Induction of Apoptotic Cells by Ectopic Expression of miR-451a in LUSQ Cells}

First, we investigated the antitumor roles of miR-451a in LUSQ cells using ectopic expression of mature miRNAs in EBC-1 and SK-MES-1 cells. Cell proliferation assays indicated significant inhibition of cell growth in miR-451a-transfected cells compared with that in mock- or control-transfected cells (Figure 2A,D).

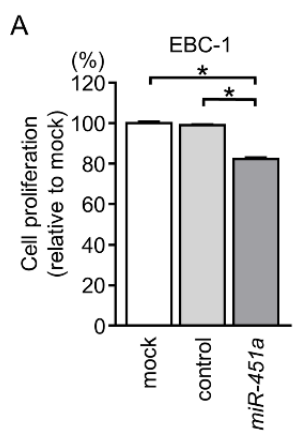

B

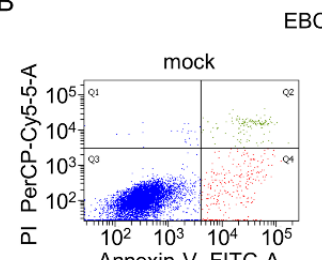

EBC-1
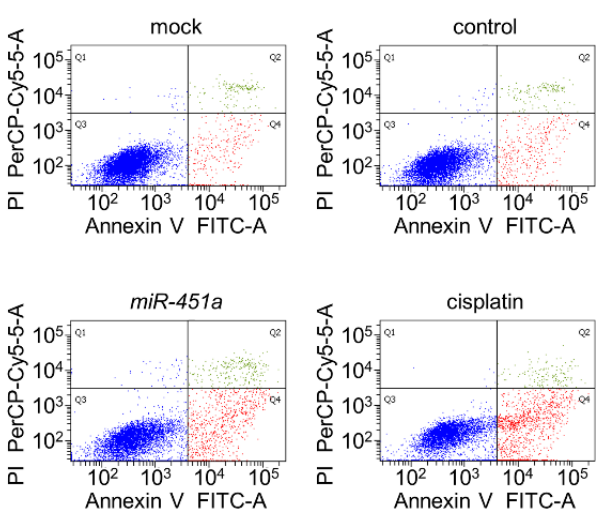

Q1 area: Dead cells, Q2 area: Late apoptotic cells,

Q3 area: Viable cells, Q4 area: Early apoptotic cells

E

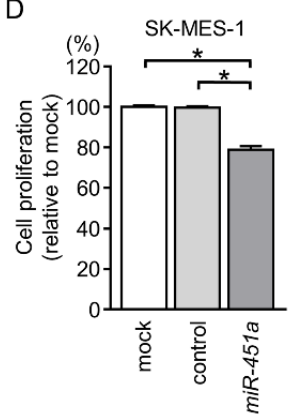

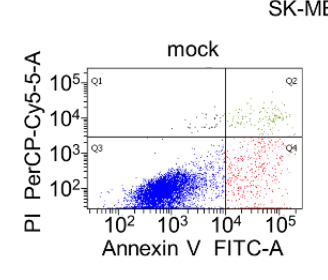

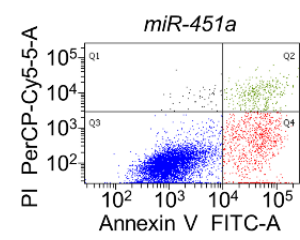

Q1 area: Dead cells, Q2 area: Late apoptotic cells,

Q3 area: Viable cells, Q4 area: Early apoptotic cells
C

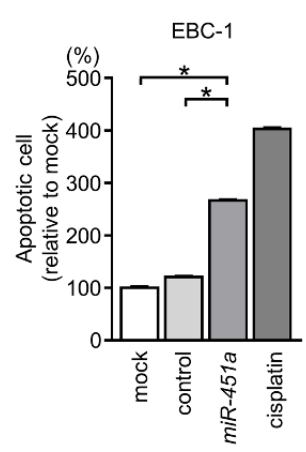

$\mathrm{F}$

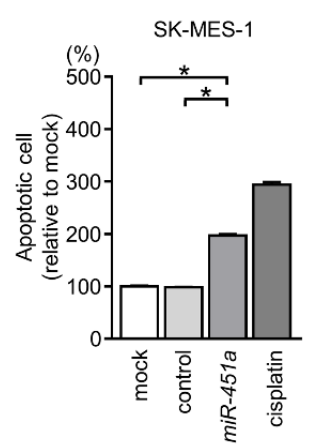

Figure 2. Cell proliferation and apoptosis assays following ectopic expression of miR-451a in LUSQ cells. (A,D) Cell proliferation was determined by XTT assays $72 \mathrm{~h}$ after transfection with miR-451a $\left({ }^{*} p<0.001\right)$. (B,E) Apoptosis assays using flow cytometry with Annexin V-FITC- and PI-PerCP-Cy5-5-A-stained cells. Cisplatin $(15 \mu \mathrm{M})$ was used as a positive control for induction of apoptosis. (C,F) Quantification of apoptotic cells following ectopic expression of miR-451a in LUSQ cells (EBC-1 and SK-MES-1). The normalized ratios of apoptotic cells are shown as histograms from FACS analyses $\left({ }^{*} p<0.001\right)$. 
We further investigated the occurrence of apoptosis using flow cytometry assays. Our data showed that the percentages of apoptotic cells were increased in miR-451a-transfected cells in comparison with those in mock- or control-transfected cells (Figure 2B,C,E,F). Moreover, restoration of $m i R-451 a$ expression promoted cleaved poly (ADP-ribose) polymerase (PARP) expression (Figure 3).

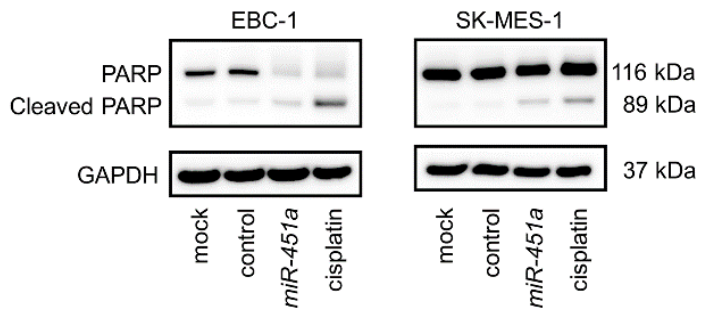

Figure 3. Western blot analyses of cleaved polymerase (PARP) as a marker of apoptosis in LUSQ cell lines. glyceraldehyde 3-phosphate dehydrogenase (GAPDH) was used as a loading control.

\subsection{Effects of Ectopic Expression of miR-451a on LUSQ Cell Migration and Invasion}

We then investigated the potential effects of $m i R-451 a$ on cell migration and invasion in LUSQ cells. Overexpression of $m i R-451 a$ attenuated cancer cell migration and invasion in comparison with that in mock- or control-transfected cells (Figure 4A,B).

A

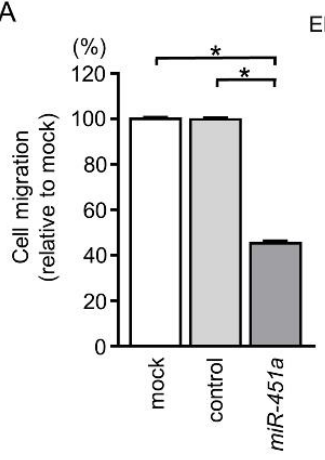

B

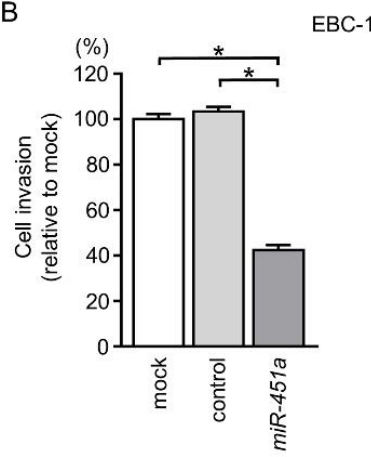

EBC-1
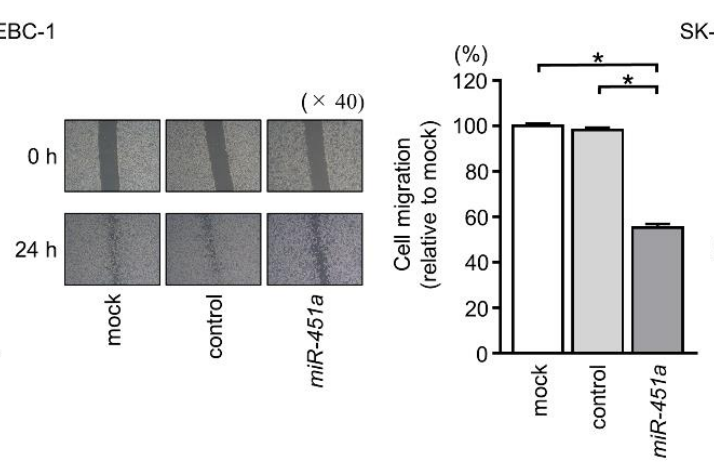

SK-MES-1

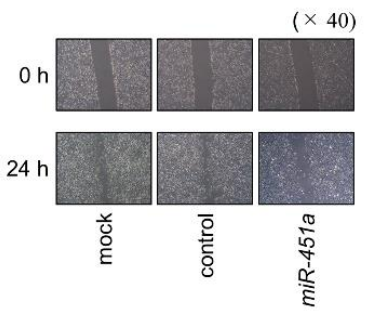

Figure 4. Cell migration and invasion assays following ectopic expression of miR-451a in LUSQ cells. (A) Cell migration was measured by wound healing assays $\left({ }^{*} p<0.001\right)$. (B) Cell invasion was determined by Matrigel invasion assays $\left({ }^{*} p<0.001\right)$. Phase-contrast micrographs of LUSQ cells in migration and micrographs of LUSQ cells in invasion assays are shown.

\subsection{Screening of Putative Target Genes by miR-451a Regulation in LUSQ Cells}

Next, we aimed to identify putative target genes of $m i R-451 a$. To this end, we performed miRNA database analyses and comprehensive gene expression assays. The search strategy for miRNA targets is presented in Figure S4. 
Using TargetScanHuman database (release 7.2), we found that 548 putative target genes had binding sites for miR-451a in their $3^{\prime}$-untranslated regions (UTRs). We then selected genes that showed increased expression in NSCLC specimens (Gene Expression Omnibus (GEO) accession number: GSE19188), merged gene expression analysis data with miR-451a-transfected SK-MES-1 cells (GEO accession number: GSE113066), and selected genes showing decreased expression. After this analysis, 15 candidate miR-451a target genes were identified (Table 2).

Table 2. Putative target genes regulated by miR-451a in LUSQ cells.

\begin{tabular}{|c|c|c|c|c|c|c|c|}
\hline \multirow{2}{*}{$\begin{array}{l}\text { Gene } \\
\text { ID }\end{array}$} & \multirow{2}{*}{$\begin{array}{l}\text { Gene } \\
\text { Symbol }\end{array}$} & \multirow[b]{2}{*}{ Description } & \multirow{2}{*}{$\begin{array}{c}\text { miR-451a } \\
\text { Transfectant } \\
\log _{3} \text { Ratio }\end{array}$} & \multicolumn{2}{|c|}{$m i R-451 a$ Target Site } & \multirow{2}{*}{$\begin{array}{l}\text { GSE19188 } \\
\text { Log FC }\end{array}$} & \multirow{2}{*}{$\begin{array}{c}\text { TCGA } \\
\text { Database5-y } \\
\text { OS } p \text {-Value }\end{array}$} \\
\hline & & & & $\begin{array}{l}\text { Conserved } \\
\text { Site }\end{array}$ & $\begin{array}{c}\text { Poorly } \\
\text { Conserved Site }\end{array}$ & & \\
\hline 3796 & $K I F 2 A$ & $\begin{array}{l}\text { kinesin family } \\
\text { member 2A } \\
\text { ATPase }\end{array}$ & -0.717 & 0 & 1 & 1.01 & 0.043 \\
\hline 23200 & АТР11B & $\begin{array}{l}\text { phospholipid } \\
\text { transporting 11B }\end{array}$ & -0.737 & 0 & 1 & 1.38 & 0.081 \\
\hline 83990 & BRIP1 & $\begin{array}{l}\text { BRCA1 interacting } \\
\text { protein C-terminal } \\
\text { helicase } 1\end{array}$ & -0.722 & 0 & 1 & 2.05 & 0.123 \\
\hline 25769 & $S L C 24 A 2$ & $\begin{array}{l}\text { solute carrier family } \\
24 \text { member } 2 \\
\text { SPC } 25, \text { NDC } 80\end{array}$ & -0.734 & 0 & 1 & 1.01 & 0.147 \\
\hline 57405 & SPC25 & $\begin{array}{l}\text { kinetochore } \\
\text { complex component } \\
\text { macrophage }\end{array}$ & -1.500 & 0 & 1 & 2.42 & 0.263 \\
\hline 4282 & MIF & $\begin{array}{l}\text { migration inhibitory } \\
\text { factor }\end{array}$ & -1.144 & 1 & 0 & 1.58 & 0.357 \\
\hline 84951 & TNS4 & tensin 4 & -0.592 & 0 & 1 & 2.56 & 0.494 \\
\hline 1362 & $C P D$ & carboxypeptidase D & -1.233 & 0 & 1 & 1.07 & 0.598 \\
\hline 23516 & SLC39A14 & $\begin{array}{l}\text { solute carrier family } \\
39 \text { member } 14\end{array}$ & -1.190 & 0 & 1 & 1.01 & 0.607 \\
\hline 5933 & RBL1 & $\begin{array}{l}\text { RB transcriptional } \\
\text { corepressor like } 1 \\
\text { solute carrier }\end{array}$ & -0.922 & 0 & 1 & 1.08 & 0.720 \\
\hline 81796 & SLCO5A1 & $\begin{array}{l}\text { organic anion } \\
\text { transporter family } \\
\text { member 5A1 }\end{array}$ & -0.795 & 0 & 1 & 1.23 & 0.732 \\
\hline 9699 & RIMS2 & $\begin{array}{l}\text { regulating synaptic } \\
\text { membrane } \\
\text { exocytosis } 2\end{array}$ & -0.515 & 0 & 1 & 1.98 & 0.815 \\
\hline 64067 & NPAS3 & $\begin{array}{c}\text { neuronal PAS } \\
\text { domain protein } 3\end{array}$ & -1.005 & 0 & 1 & 1.23 & 0.833 \\
\hline 2668 & GDNF & $\begin{array}{l}\text { glial cell derived } \\
\text { neurotrophic factor }\end{array}$ & -1.289 & 0 & 1 & 1.01 & 0.866 \\
\hline 23657 & SLC7A11 & $\begin{array}{l}\text { solute carrier family } \\
7 \text { member } 11\end{array}$ & -0.594 & 0 & 1 & 2.01 & 0.878 \\
\hline
\end{tabular}

Lower and upper percentiles of The Cancer Genome Atlas (TCGA) database were both 33. GSE: Gene Expression Omnibus dataset results; FC: fold change; OS: overall survival.

We then investigated the clinical impact of these target genes in LUSQ using TCGA database analyses. Among these candidate genes, high expression of KIF2A was significantly associated with LUSQ pathogenesis (5-year OS: $p=0.043$ and 5-year DFS: $p=0.028$; Figure 5). Furthermore, among patients with adjusting clinical stage and age distribution, patients with high expression of KIF $2 \mathrm{~A}$ also showed significantly poor prognosis compared with patients with low expression of KIF2A (5-year OS: $p=0.029$; Figure S5A). Moreover, among LUSQ patients with early clinical stage (stage I and II), high expression of KIF2A was significantly associated not only with prognosis but also with cancer recurrence (Figure S5B). Therefore, we focused on KIF2A and validated the functional implications in LUSQ cells.

In addition, TCGA database analyses showed that high expression of KIF2A was associated with poor prognosis in patients with renal papillary cell carcinoma and hepatocellular carcinoma (Figure S3). 
KIF2A expression
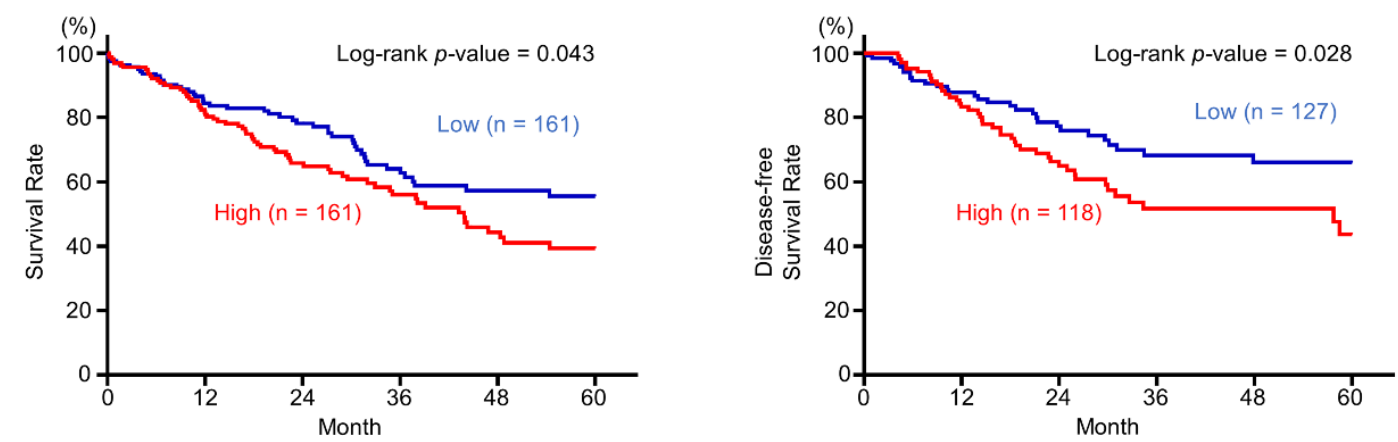

Figure 5. Kaplan-Meier analyses of KIF2A expression. High KIF2A expression group (red line); low KIF2A expression group (blue line).

\subsection{Expression of KIF2A Was Directly Controlled by miR-451a in LUSQ Cells}

Next, we examined the control of KIF2A expression by miR-451a. Levels of KIF2A mRNA and protein were significantly suppressed by $m i R-451 a$ transfection into EBC- 1 and SK-MES- 1 cells compared with those in mock- or control-transfected cells (Figure 6A,B).

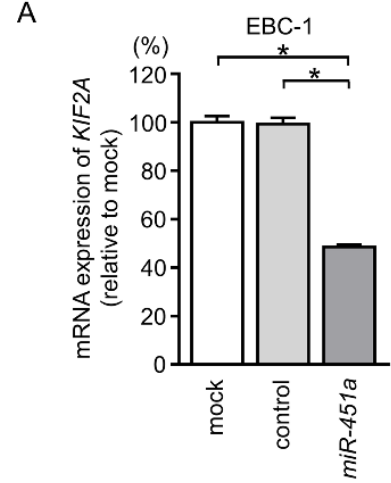

B

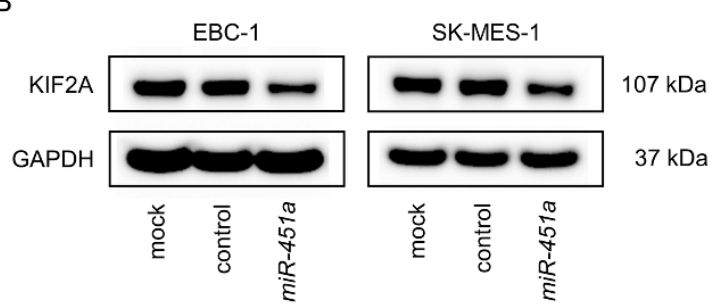

C
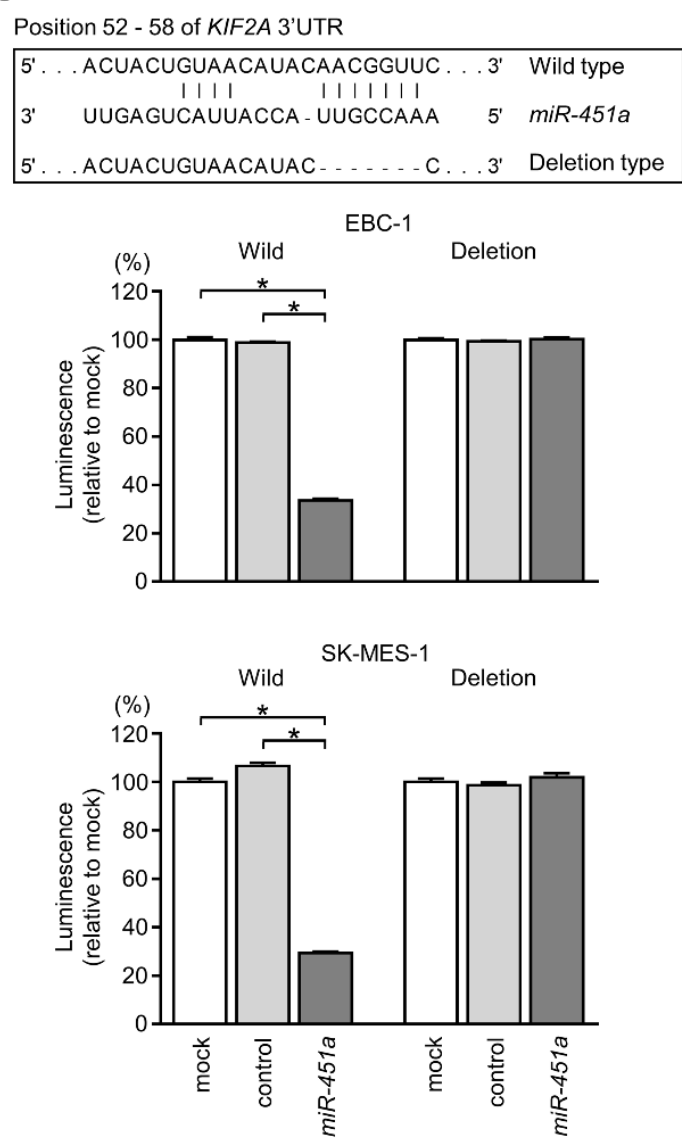

Figure 6. Direct regulation of KIF2A expression by miR-451a in LUSQ cells. (A) KIF2A mRNA expression

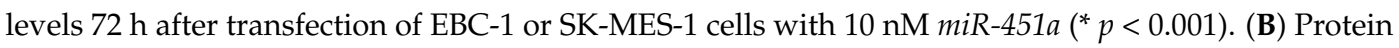
expression of KIF2A $72 \mathrm{~h}$ after transfection with miR-451a. (C, upper) Putative miR-451a binding site in the $3^{\prime}$-UTR of KIF2A mRNA. (C, lower) Dual luciferase reporter assays using vectors encoding putative miR-451a target sites in the KIF2A $3^{\prime}$-UTR (position 52-58) for both wild-type and deleted regions. Normalized data were calculated as Renilla/firefly luciferase activity ratios $\left({ }^{*} p<0.001\right)$. 
Luciferase assays were then used to confirm the direct binding of miR-451a to KIF2A mRNA. Based on an analysis of the TargetScanHuman database (Release 7.2), there was a putative binding site for miR-451a in the $3^{\prime}$-UTR of KIF2A (position 52-58, Figure 6C). Accordingly, luciferase reporter assays were performed using a vector harboring these sequences in order to determine whether $m i R-451 a$ directly regulated KIF2A expression in a sequence-dependent manner.

We observed greatly reduced luminescence after transfection with miR-451a and the vector carrying the wild-type $3^{\prime}$-UTR of KIF2A. Transfection with the deletion-type vector did not reduce luminescence intensities in EBC-1 or SK-MES-1 cells (Figure 6C). These findings demonstrated that miR-451a bound directly to the $3^{\prime}$-UTR of KIF2A.

We also investigated the correlation between $m i R-451 a$ and KIF2A expression in LUSQ patients. TCGA database analyses showed that a negative correlation was detected between miR-451a and KIF2 $A$ expression in LUSQ patients ( $r=-0.180$ and $p=0.010$; Figure S6).

\subsection{Aberrant Expression of KIF2A and Its Clinical Significance in LUSQ}

We then validated the expression of KIF2A protein in LUSQ clinical tissues using immunohistochemical analyses. Compared with normal lung specimens, KIF2A protein was strongly expressed in LUSQ tissues (Figure 7A-D and Table 3).

A
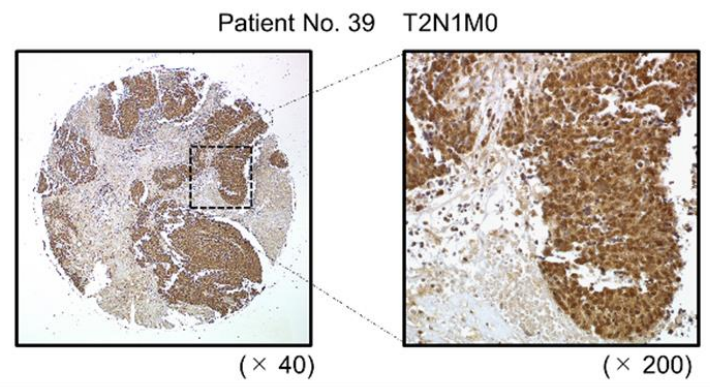

C

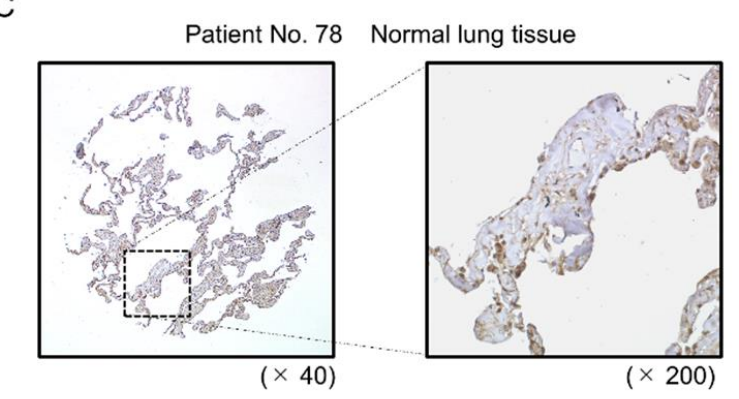

B

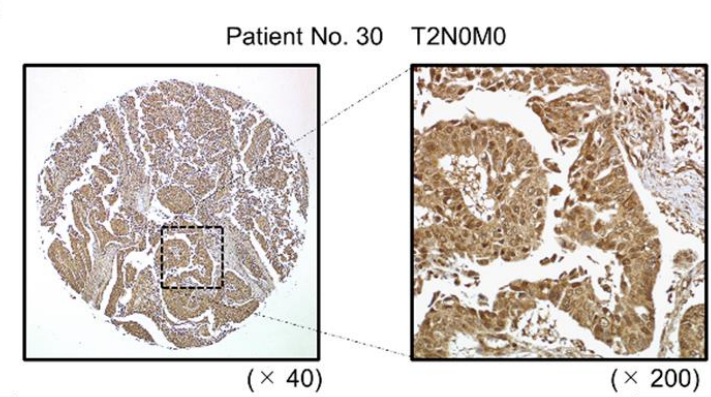

D

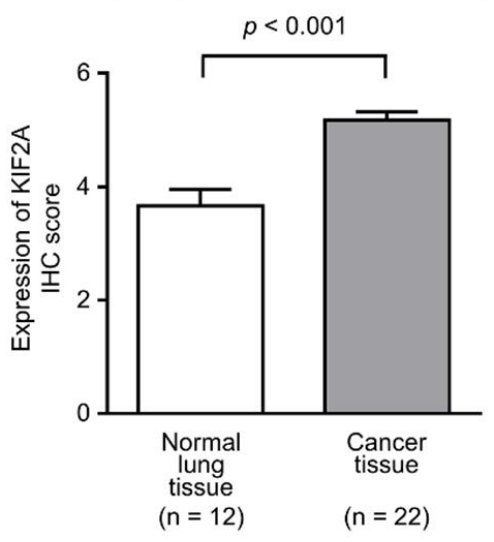

Figure 7. Aberrant expression of KIF2A in clinical LUSQ specimens. (A-C) Aberrant expression of KIF2A was observed in the cytoplasm of cancer cells, whereas negative or low expression of KIF2A was observed in normal cells. (D) Comparison of KIF2A expression scoring across clinical lung specimens. KIF2A expression in LUSQ tissues was significantly higher than that in normal lung tissue $\left({ }^{*} p<0.001\right)$. 
Table 3. Characteristics and immunohistochemical status of patients in tissue microarray analysis.

A. Immunohistochemical status and characteristics of LUSQ cases

\begin{tabular}{|c|c|c|c|c|c|c|c|}
\hline Patient No. & Grade & $\mathrm{T}$ & $\mathbf{N}$ & $\mathbf{M}$ & $\begin{array}{l}\text { Pathological } \\
\text { Stage }\end{array}$ & $\begin{array}{l}\text { Immunohistochemical } \\
\text { Staining Intensity }\end{array}$ & $\begin{array}{l}\text { Immunohistochemical } \\
\text { Staining Extensity }\end{array}$ \\
\hline 23 & 2 & 2 & 1 & 0 & IIB & $(+)$ & $(+++)$ \\
\hline 24 & 2 & 2 & 0 & 0 & IB & $(+++)$ & $(+++)$ \\
\hline 25 & 2 & 1 & 0 & 0 & IA & $(+++)$ & $(+++)$ \\
\hline 26 & 1 & 2 & 1 & 0 & IIB & $(++)$ & $(+++)$ \\
\hline 27 & 2 & 1 & 0 & 0 & IA & $(++)$ & $(+++)$ \\
\hline 28 & 1 & 3 & 0 & 0 & IIB & $(++)$ & $(+++)$ \\
\hline 29 & 1 & 2 & 0 & 0 & IB & $(+++)$ & $(+++)$ \\
\hline 30 & 2 & 2 & 0 & 0 & IB & $(+++)$ & $(+++)$ \\
\hline 31 & 3 & 2 & 0 & 0 & IB & $(++)$ & $(+++)$ \\
\hline 32 & 3 & 2 & 1 & 0 & IIB & $(+)$ & $(+++)$ \\
\hline 33 & 3 & 2 & 0 & 0 & IB & $(++)$ & $(+++)$ \\
\hline 34 & 3 & 2 & 1 & 0 & IIB & $(++)$ & $(+++)$ \\
\hline 35 & 2 & 3 & 1 & 0 & IIIA & $(++)$ & $(+++)$ \\
\hline 36 & 3 & 2 & 1 & 0 & IIA & $(++)$ & $(+++)$ \\
\hline 37 & 3 & 3 & 0 & 0 & IIB & $(++)$ & $(+++)$ \\
\hline 38 & 3 & 2 & 0 & 0 & IB & $(+++)$ & $(+++)$ \\
\hline 39 & 3 & 2 & 1 & 0 & IIB & $(+++)$ & $(+++)$ \\
\hline 40 & 3 & 2 & 0 & 0 & IB & $(+++)$ & $(+++)$ \\
\hline 41 & $2-3$ & 3 & 0 & 0 & IIB & $(++)$ & $(+++)$ \\
\hline 42 & 3 & 1 & 2 & 0 & IIIA & $(+)$ & $(+++)$ \\
\hline 43 & 3 & 2 & 0 & 0 & IB & $(++)$ & $(+++)$ \\
\hline 44 & 3 & 2 & 0 & 0 & IB & $(++)$ & $(+++)$ \\
\hline
\end{tabular}

B. Immunohistochemical status of noncancerous cases

\begin{tabular}{ccc}
\hline Patient No. & $\begin{array}{c}\text { Immunohistochemical } \\
\text { Staining Intensity }\end{array}$ & $\begin{array}{c}\text { Immunohistochemical } \\
\text { Staining Extensity }\end{array}$ \\
\hline 69 & $(++)$ & $(++)$ \\
70 & $(++)$ & $(+++)$ \\
71 & $(+)$ & $(++)$ \\
72 & $(+)$ & $(++)$ \\
73 & $(+)$ & $(++)$ \\
74 & $(++)$ & $(+++)$ \\
75 & $(+)$ & $(++)$ \\
76 & $(++)$ & $(++)$ \\
77 & $(+)$ & $(+)$ \\
78 & $(+)$ & $(++)$ \\
80 & $(++)$ & $(+++)$ \\
\hline
\end{tabular}

The pathological stages of lung cancer were classified according to Lung Cancer TNM classification, 7th Edition.

Moreover, multivariate analysis showed that KIF2A overexpression was an independent predictive factor for OS (hazard ratio $=1.493, p=0.034$; Figure 8). 
A

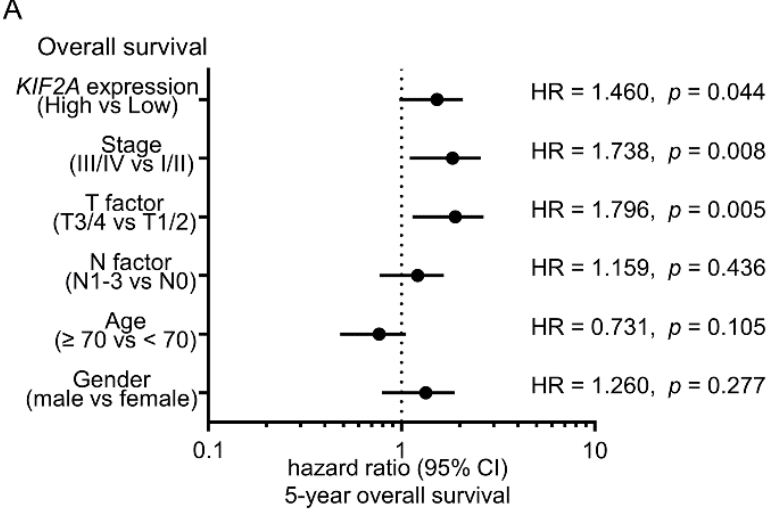

B

Overall survival

Multivariate cox proportional hazards regression analysis

\begin{tabular}{|c|c|c|c|}
\hline & hazard ratio & $95 \% \mathrm{Cl}$ & $p$-value \\
\hline KIF2A & 1.493 & $1.030-2.163$ & 0.034 \\
\hline Stage & - & - & 0.200 \\
\hline T factor & 1.868 & $1.240-2.815$ & 0.003 \\
\hline
\end{tabular}

Figure 8. Clinical significance of KIF2A expression in patients with LUSQ. (A) Forest plot of univariate Cox proportional hazards regression analysis of 5-year overall survival. (B) Multivariate Cox proportional hazards regression analysis of 5-year overall survival using TCGA database.

\subsection{Effects of KIF2A Knockdown on Cell Proliferation and Induction of Apoptotic Cells in LUSQ Cells}

To further confirm the role of KIF2A in the pathogenesis of LUSQ, we next evaluated the effects of KIF2A downregulation in EBC-1 and SK-MES-1 cells using small interfering RNAs (siRNAs). Both si-KIF2A-1 and si-KIF2A-2 effectively decreased the expression of KIF2A mRNA and protein (Figure 9A,B).

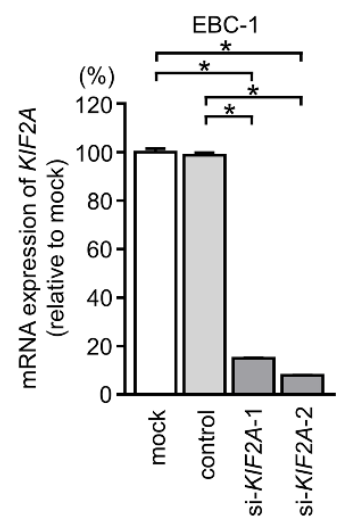

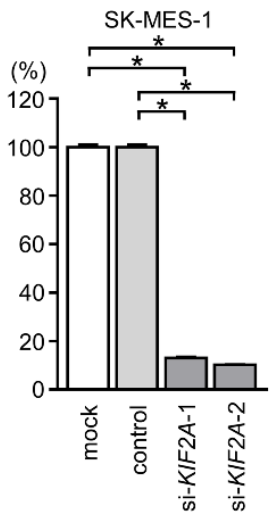

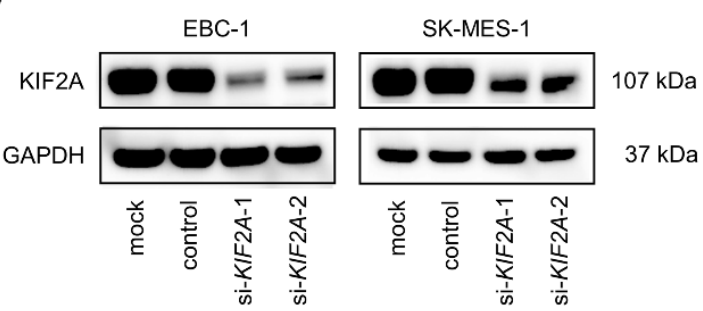

Figure 9. Efficiency of $K I F 2 A$ silencing by siRNA transfection. (A) mRNA expression of KIF2A $72 \mathrm{~h}$ after transfection with si-KIF2A in EBC-1 and SK-MES-1 cells. $\left({ }^{*} p<0.001\right)$. (B) KIF2A protein expression was determined by Western blot analysis $72 \mathrm{~h}$ after transfection with si-KIF2A in EBC-1 and SK-MES-1 cells.

Cancer cell proliferation was significantly suppressed by si-KIF2A transfection in comparison with those in mock- or control-transfected LUSQ cells (Figure 10A,D). 
A

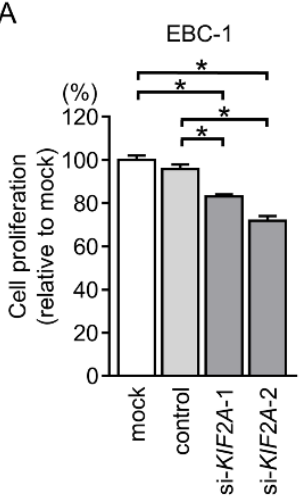

B
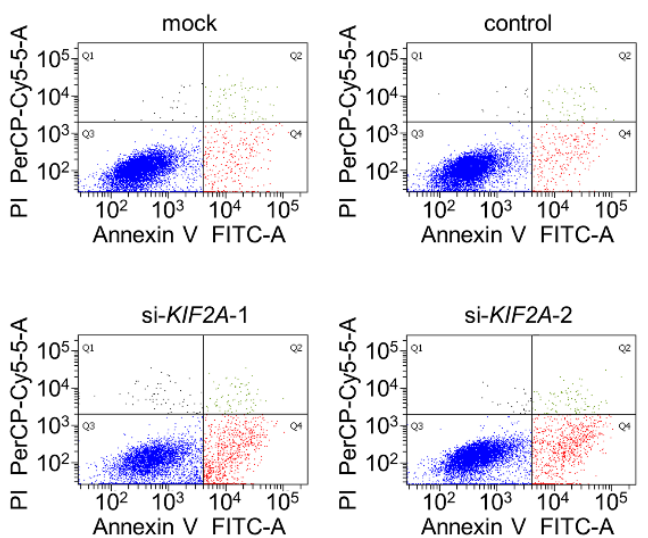

Q1 area: Dead cells,

Q2 area: Late apoptotic cells,

Q3 area: Viable cells,

Q4 area: Early apoptotic cells
C

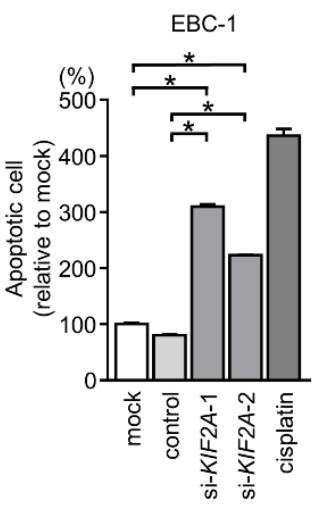

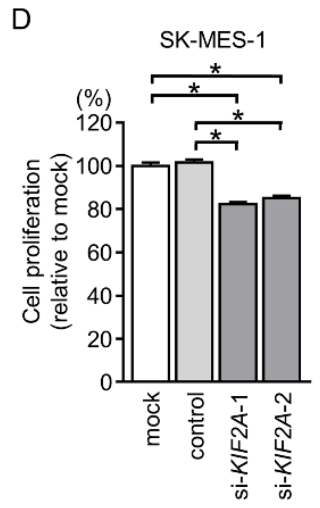

E

SK-MES-1

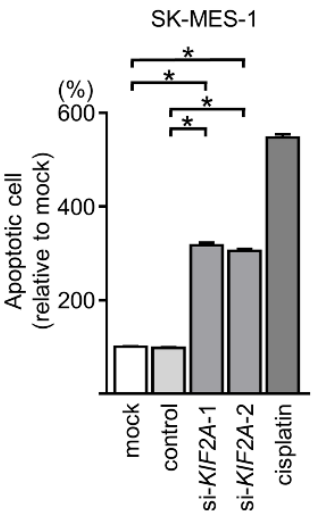

Figure 10. Inhibition of cell proliferation and induction of apoptotic cells by silencing of KIF2A expression in LUSQ cells. (A,D) Cell proliferation was identified by XTT assays $72 \mathrm{~h}$ after transfection with si-KIF2A-1 and si-KIF2A-2 ( $\left.{ }^{*} p<0.001\right)$. (B,E) Apoptosis was determined by flow cytometry. Cisplatin $(15 \mu \mathrm{M})$ was used as a positive control for induction of apoptosis. (C,F) Quantification of apoptotic cells by silencing of KIF2A expression in LUSQ cells (EBC-1 and SK-MES-1). The normalized ratios of apoptotic cells are shown as histograms from FACS analyses $\left({ }^{*} p<0.001\right)$.

Moreover, the apoptotic cell numbers were increased in si-KIF2A transfected cells compared with those in mock- or control-transfected cells (Figure 10B,C,E,F). Cleaved PARP expression was also detected in si-KIF2A-transfected cells (Figure 11). 


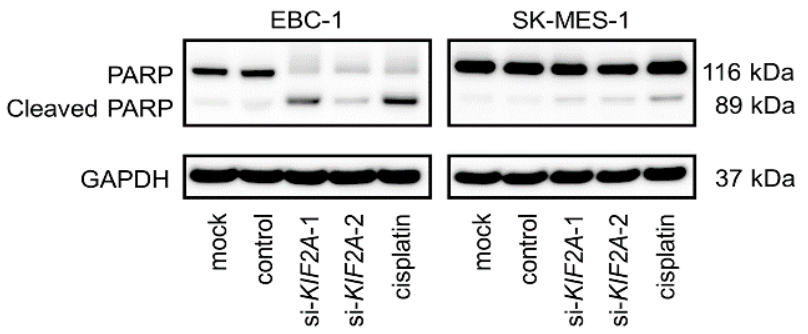

Figure 11. Western blot analyses of cleaved PARP as a marker of apoptosis in LUSQ cell lines.

\subsection{Effects of KIF2A Silencing on Cancer Cell Migration and Invasion in LUSQ Cells}

Further analyses showed that cancer cell motility, including migration and invasive abilities, was markedly inhibited by knockdown of KIF $2 A$ via si-KIF $2 A$ transfection compared with those in mockor control-transfected LUSQ cells (Figure 12A,B).

A

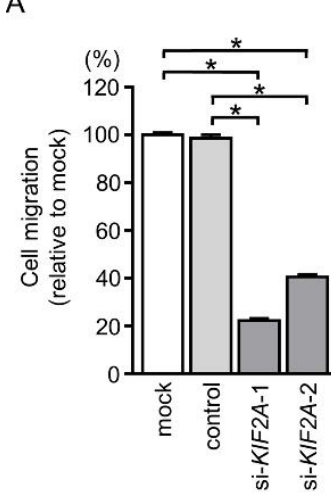

B

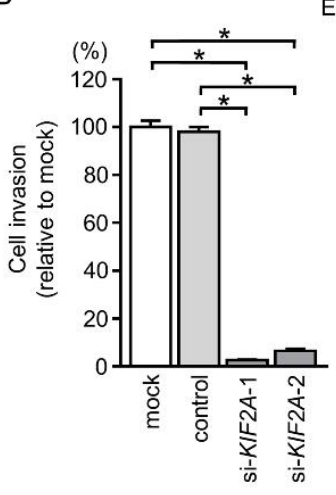

$\mathrm{EBC}-1$

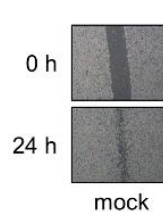

$0 \mathrm{~h}$

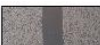

$24 \mathrm{~h}$

si-KIF2A-1

EBC-1

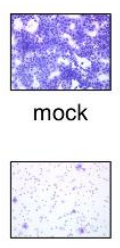

si-KIF2A-1

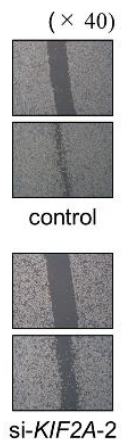

$(\times 200)$

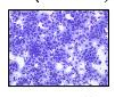

control

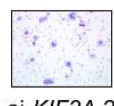

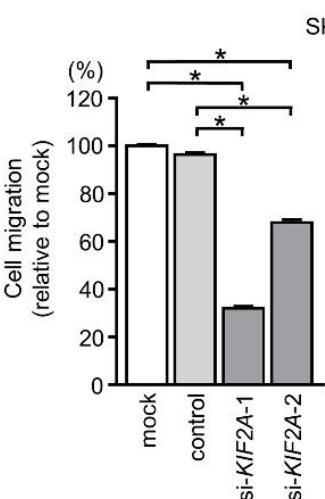

SK-MES-1

$\mathrm{Oh}$
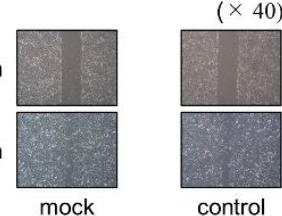

$\mathrm{Oh}$
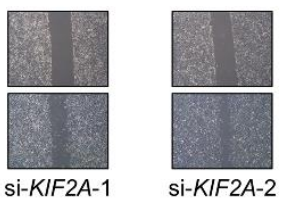

si-KIF2A-1

si-KIF2A-2

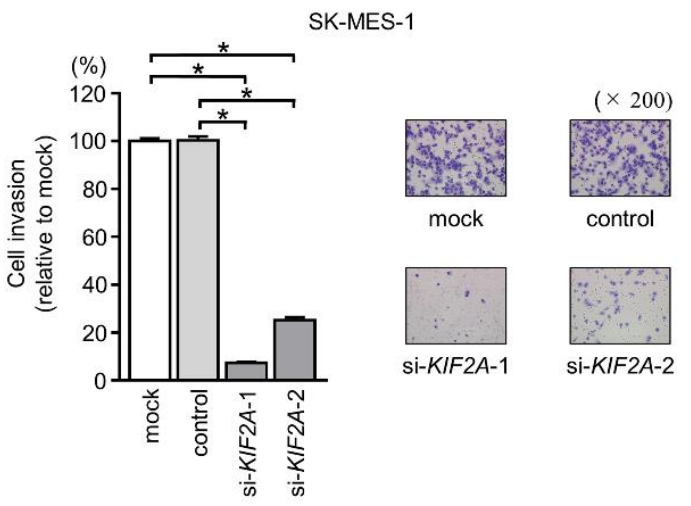

Figure 12. Effects of KIF2A silencing on cell migration and invasive abilities in LUSQ cells. (A) Cell migration was measured by wound healing assays ( $\left.{ }^{*} p<0.001\right)$. (B) Cell invasion was determined by Matrigel invasion assays $\left({ }^{*} p<0.001\right)$.

\subsection{Identification of KIF2A-Mediated Downstream Pathways in LUSQ Cells}

Based on our above findings, we then evaluated the downstream genes regulated by KIF2A using genome-wide gene expression analyses and in silico analyses in si-KIF2A-transfected SK-MES-1 cells. Our strategy is shown in Figure S7. In total, 3621 genes were identified as downregulated genes in si-KIF2A-transfected cells compared with that in mock-transfected cells (GEO accession number: GSE123318). Of these 3621 genes, 92 genes were upregulated in NSCLC clinical specimens (GEO accession number: GSE19188). 
As a result of classifying 92 genes into KEGG pathways, 5 pathways were identified, including cell cycle, p53 signaling pathway and cell cycle, p53 signaling pathway, DNA replication, and pathways in cancer (Tables 4 and 5).

Table 4. Significantly enriched annotations regulated by KIF2A in LUSQ cells.

\begin{tabular}{ccl}
\hline No. of Genes & $p$-Value & \multicolumn{1}{c}{ Annotations } \\
\hline 10 & $5.59 \times 10^{-12}$ & $($ KEGG) 04110: Cell cycle \\
3 & $5.71 \times 10^{-5}$ & (KEGG) 04115: p53 signaling pathway \\
- & - & (KEGG) 04110: Cell cycle \\
4 & $7.56 \times 10^{-5}$ & (KEGG) 04115: p53 signaling pathway \\
3 & $1.36 \times 10^{-4}$ & (KEGG) 03030: DNA replication \\
5 & $1.68 \times 10^{-3}$ & $($ KEGG) 05200: Pathways in cancer \\
\hline
\end{tabular}

Table 5. Downstream genes regulated by KIF2A among significantly enriched pathways in LUSQ cells.

\begin{tabular}{|c|c|c|c|}
\hline $\begin{array}{c}\text { Gene } \\
\text { Symbol }\end{array}$ & Description & $\begin{array}{c}\text { si-KIF2A Transfectant } \\
\log _{2} \text { Ratio }\end{array}$ & $\begin{array}{c}\text { GSE19188 } \\
\text { Log FC }\end{array}$ \\
\hline \multicolumn{4}{|l|}{ Cell cycle } \\
\hline CCNE2 & cyclin E2 & -0.730 & 2.04 \\
\hline MCM4 & minichromosome maintenance complex component 4 & -0.925 & 3.13 \\
\hline CCNA2 & cyclin $\mathrm{A} 2$ & -0.563 & 3.25 \\
\hline CCNE1 & cyclin E1 & -1.099 & 2.23 \\
\hline CHEK1 & checkpoint kinase 1 & -0.586 & 2.76 \\
\hline ORC6 & origin recognition complex subunit 6 & -0.565 & 2.26 \\
\hline CDC6 & cell division cycle 6 & -0.529 & 3.31 \\
\hline ORC1 & origin recognition complex subunit 1 & -0.600 & 2.72 \\
\hline$C D C 45$ & cell division cycle 45 & -0.524 & 3.83 \\
\hline MCM2 & minichromosome maintenance complex component 2 & -0.703 & 2.41 \\
\hline \multicolumn{4}{|c|}{ p53 signaling pathway, cell cycle } \\
\hline CCNE2 & cyclin E2 & -0.730 & 2.04 \\
\hline CCNE1 & cyclin E1 & -1.099 & 2.23 \\
\hline CHECK1 & checkpoint kinase 1 & -0.586 & 2.76 \\
\hline \multicolumn{4}{|c|}{ p53 signaling pathway } \\
\hline CCNE2 & cyclin E2 & -0.730 & 2.04 \\
\hline CCNE1 & cyclin E1 & -1.099 & 2.23 \\
\hline CHEK1 & checkpoint kinase 1 & -0.586 & 2.76 \\
\hline RRM2 & ribonucleotide reductase regulatory subunit M2 & -0.578 & 3.00 \\
\hline \multicolumn{4}{|c|}{ DNA replication } \\
\hline MCM4 & minichromosome maintenance complex component 4 & -0.925 & 3.13 \\
\hline MCM2 & minichromosome maintenance complex component 2 & -0.703 & 2.41 \\
\hline RFC4 & replication factor $C$ subunit 4 & -0.688 & 2.00 \\
\hline \multicolumn{4}{|c|}{ Pathway in cancer } \\
\hline MMP9 & matrix metallopeptidase 9 & -0.531 & 2.04 \\
\hline CCNE2 & cyclin E2 & -0.730 & 2.04 \\
\hline CBLC & $\mathrm{Cbl}$ proto-oncogene $\mathrm{C}$ & -0.628 & 3.04 \\
\hline CCNE1 & cyclin E1 & -1.099 & 2.23 \\
\hline RAD51 & RAD51 recombinase & -0.594 & 2.09 \\
\hline
\end{tabular}

GSE: Gene Expression Omnibus dataset results; FC: fold change.

\section{Discussion}

In the human genome, several miRNAs encoded in close proximity within a chromosome region are defined as clustered miRNAs. Analyses of our original miRNA signatures by RNA sequencing revealed that several miRNA clusters, including miR-1/miR-133a, miR-206/miR-133b, $m i R-23 b / m i R-27 b / m i R-24-1, m i R-143 / m i R-145$, and $m i R-221 / m i R-222$, are frequently downregulated in 
several types of cancer tissues [20-27]. Our previous studies showed that these miRNA clusters act as antitumor miRNAs by targeting several oncogenic genes [20-27]. In LUSQ cells, miR-1 and miR-133a are significantly downregulated in LUSQ tissues, and ectopic expression of these miRNAs inhibits cancer cell malignant phenotypes [20]. Furthermore, CORO1C is coordinately regulated by miR-1 and miR-133a, and aberrant expression of CORO1C enhances the migration and invasive abilities of LUSQ cells [20].

Notably, our miRNA signatures demonstrated that miR-144-5p, miR-144-3p, and miR-451a frequently showed decreased expression levels in several cancers, including head and neck cancer, renal cell carcinoma, and bladder cancer. Moreover, these three miRNAs were found to form a miRNA cluster in human chromosome 17q11.2 [28-31]. Our previous studies revealed that the members of this miRNA cluster act as antitumor miRNAs by targeting oncogenic genes, including CCNE1, CCNE2, ESDN/DCBLD2, SDC3, and PMM2 [28-31]. Recently, we also demonstrated that miR-144-5p and $m i R-144-3 p$ have antitumor functions in LUSQ cells and that their expression predicts a poor prognosis [19]. Interestingly, in this study, miR-451a also acts as an antitumor miRNA, and low miR-451a expression predicts poor prognosis for patients with LUSQ. Based on our previous studies and current data, we have concluded that members of this miRNA cluster are closely involved in LUSQ pathogenesis.

Downregulation of miR-451a has been reported in other types of cancers and its ectopic expression inhibits cancer cell aggressiveness, including that in gastric cancer, glioblastoma, nasopharyngeal cancer, renal cell carcinoma, and prostate cancer [28,30,32-35]. In LUAD cells, ectopic expression of miR-451a inhibits cancer cell proliferation and enhances apoptosis via targeting of RAB14 and AKT signaling pathways [36]. Furthermore, downregulation of $m i R-451$ was detected in NSCLC tissues and its expression was an independent predictor of prognosis of NSCLC, such as advanced disease stage and metastasis [37]. Interestingly, ectopic expression of miR-451 suppressed cell proliferation, migration and activation of AKT through targeting MIF in NSCLC cells [37]. Based on these facts, we concluded that miR-451a is a pivotal antitumor miRNA in human cancers through targeting of several oncogenic genes.

Elucidation of molecular mechanisms of aberrantly expressed miRNAs in cancer cells is an important issue for cancer research. Previous study showed that expression of miR-451a was significantly recovered by treatment with 5-aza-2'-deoxycitidine or sodium plenylbutyrate in NSCLC cells [36]. These results indicated that DNA hypermethylation was caused to downregulation of miR-451a in NSCLC. Recent study of prostate cancer showed that HP1 $\gamma$ was upregulated by oncogenic $c-M Y C$ and $H P 1 \gamma$ suppressed to expression of miR-451a in prostate cancer cells [38]. Further investigation of the molecular mechanism of downregulation of miR-451a in LUSQ cells is indispensable.

As a unique natural feature of miRNAs, a single miRNA can regulate vast numbers of RNA transcripts. The RNA transcripts controlled by miRNA vary depending on the cell type. Therefore, the next task is to find the oncogenic genes and pathways that are controlled by antitumor miR-451a in LUSQ cells. In total, 15 putative oncogenic targets under miR-451a regulation were successfully identified in this study. Among these targets, MIF was reported by another group as a direct target of $m i R-451 a$, and its expression was shown to enhance cancer cell growth and invasion in gastric cancer and nasopharyngeal cancer [32,34]. Understanding the targets that are regulated by the miR-451a in LUSQ cells may contribute to our knowledge of LUSQ molecular pathogenesis.

In this study, we focused on KIF2A because its expression was significantly associated with a worse prognosis for patients with LUSQ. Our current data confirmed that aberrant expression of KIF2A enhanced cancer cell aggressiveness in LUSQ cells. KIF2A is a member of the kinesin- 13 family (other members are KIF2B, KIF2C, and KIF24), and its main function is microtubule depolymerization, a critical event for mitotic progression and spindle assembly [39-41]. Recently, several reports have shown that aberrantly expressed KIF2A is detected in several cancers, including breast, oral, colorectal, and ovarian cancers, and its expression contributes to cancer cell malignancies [42-45]. In a recent study, 
expression of KIF2A was found to be closely associated with TNM stage and lymph node metastasis in LUAD [46]. Knockdown of KIF2A in LUAD cells inhibits cell proliferation and induces apoptosis [46], consistent with our current findings of LUSQ cells. In lung cancers (LUSQ and LUAD), aberrantly expressed KIF2A may serve as a valuable prognosis marker and candidate for therapeutic targeting.

Furthermore, to investigate KIF2A-mediated oncogenic pathways in LUSQ cells, we applied genome-wide gene expression analyses and in silico analyses using KIF2A-knockdown LUSQ cells. We identified several KIF2A-mediated pathways, including cell cycle, p53 signaling, and DNA replication. Among the genes involved in these pathways, a previous study showed that overexpression of MCM2 is associated with OS in patients with LUSQ and that its aberrant expression participates in the development and progression of LUSQ [47]. Moreover, MCM4 was detected in clinical specimens of LUSQ [48]. Aberrant expression of these oncogenic genes contributes to the development, metastasis, and drug resistance of LUSQ. Elucidation of novel RNA networks controlled by antitumor miRNAs will accelerate the journey to a comprehensive understanding of LUSQ molecular pathogenesis.

\section{Materials and Methods}

\subsection{Clinical Samples Collection, Cell Lines, and RNA Extraction}

The current study was approved by the Bioethics Committee of Kagoshima University Hospital (Kagoshima, Japan; approval numbers: 26-164). Prior written informed consent and approval for this study were obtained from each patient. We collected 50 lung samples at Kagoshima University Hospital from 2010 to 2013. The pathological stages of LUSQ were classified according to the International Association for the Study of Lung Cancer TNM classification, 7th Edition [49]. Lung cancer samples and noncancerous tissues were obtained from the lung specimens resected by thoracic surgery for LUSQ. The extraction of RNA from formalin-fixed, paraffin-embedded specimens was performed as described in a previous study [17].

Two LUSQ cell lines, EBC-1 and SK-MES-1, were obtained from the Japanese Cancer Research Resources Bank (Osaka, Japan) and the American Type Culture Collection (ATCC; Manassas, VA, USA), respectively. The procedures for cell culture, extraction of total RNA, and extraction of protein from LUSQ cell lines were described in our earlier manuscripts $[17,18,50]$.

\subsection{Quantitative Real-Time Reverse Transcription Polymerase Chain Reaction (qRT-PCR)}

The methods for qRT-PCR have been described previously [16,50,51]. TaqMan qRT-PCR assays (assay ID: 001141; Applied Biosystems, Foster City, CA, USA) were used to validate miR-451a expression. To normalize the data, the expression of RNU48 (assay ID: 001006; Applied Biosystems) was used. KIF2A expression values were measured using TaqMan probes and primers (assay ID: Hs00189636_m1; Applied Biosystems). Expression of glyceraldehyde 3-phosphate dehydrogenase (GAPDH; assay ID: Hs99999905_m1; Applied Biosystems) was used for normalization.

\subsection{Transfections with Mature miRNA and siRNA into LUSQ Cell Lines}

We used the following mature miRNA species and siRNAs in this study: mirVana miRNA mimic, hsa-miR-451a (product ID: MC10286; Applied Biosystems), and Stealth Select RNAi siRNA, si-KIF2A (P/N: HSS105799 and HSS180178; Invitrogen, Carlsbad, CA, USA). Anti-miR Negative Control \#1 (catalog no: AM17010; Applied Biosystems) was used as a negative control. The method for transfection is described in our previous studies $[15,16,50,52]$.

\subsection{Cell proliferation, Migration, and Invasion Assays}

Cell proliferation activity was determined by XTT assays using a Cell Proliferation Kit (Biological Industries, Beit-Haemek, Israel). Cell migration ability was evaluated with wound healing assays. 
Cell invasion ability was determined with Corning Matrigel Invasion Chambers (Discovery Labware, Inc., Bedford, MA, USA). Detailed procedures were described in our earlier reports [16,20].

\subsection{Apoptosis Assays}

Apoptotic cells were detected using a FITC Annexin V Apoptosis Detection Kit (BD Biosciences, Bedford, MA, USA) according to the manufacturer's protocol and analyzed by BD FACS Celesta Flow Cytometer (BD Biosciences). Cells were identified as viable cells, dead cells, and early and late apoptotic cells, and the percentages of apoptotic cells under different experimental conditions were compared [53]. We used $15 \mu \mathrm{M}$ cisplatin as a positive control.

\subsection{Identification of Putative Target Genes Regulated by miR-451a in LUSQ Cells}

The strategy for selecting target genes in this study is shown in Figure S4. We selected putative target genes having binding sites for miR-451a using TargetScanHuman ver.7.2 (http:/ / www.targetscan. org/vert_72/) (data was downloaded on 13 July 2018). We then examined the expression levels of putative miR-451a targets in the NSCLC clinical expression data from the GEO database (GSE19188). The microarray data were deposited in the GEO repository under accession number GSE113066.

\subsection{Clinical Database Analysis}

The following databases were applied to investigate the clinical significance of gene expression in patients with LUSQ: TCGA database (https://tcga-data.nci.nih.gov/tcga/), cBioPortal (http: //www.cbioportal.org/), and OncoLnc (http://www.oncolnc.org/) (data was downloaded on August 8,2018$)[54,55]$. Lower and upper percentiles of TCGA database were both 33, without additional comments.

\subsection{Plasmid Construction and Dual-Luciferase Reporter Assay}

Partial sequences of the wild-type KIF2A 3'-UTR, either containing or lacking the miR-451a target site, were cloned into the psiCHECK-2 vector (C8021; Promega, Madison, WI, USA).

After cotransfecting miRNA and the constructed vector into EBC-1 and SK-MES-1 cells, firefly and Renilla luciferase activities were determined using a Dual-Luciferase Reporter Assay System (catalog no: E1960; Promega). The procedure is described in our previous studies $[15,16,50,52,56]$.

\subsection{Western Blotting and Immunohistochemistry}

Membranes were immunoblotted with rabbit polyclonal anti-KIF2A antibodies (1:1000 dilution; ab197988; Abcam, Cambridge, UK) and monoclonal anti-GAPDH antibodies (1:20000 dilution; MAB374; EMD Millipore, Billerica, MA, USA). The procedures for western blotting were as described previously [16,18].

Immunohistochemistry was performed with a VECTASTAIN Universal Elite ABC Kit (catalog no: PK-6200; Vector Laboratories, Burlingame, CA, USA) according to the manufacturer's protocol. The characteristics of patients included in the tissue microarray (catalog no: LC813a; US Biomax, Inc., Derwood, MD, USA) are shown in Table 3. The procedure for immunohistochemistry is described in our earlier reports $[16,21,50]$.

\subsection{Identification of Downstream Targets Regulated by KIF2A in LUSQ Cells}

The microarray expression profiles of si-KIF2A transfectants were deposited in the GEO repository under accession number GSE123318. KEGG pathway categories, determined with the GeneCodis program (http:/ / genecodis.cnb.csic.es/), were used to reveal the signaling pathways regulated by KIF2A [57]. The strategy for identification of signaling pathways is shown in Figure S7. 


\subsection{Statistical Analysis}

All data were analyzed using SPSS version 25 software (IBM SPSS, Chicago, IL, USA). To assess the significance of differences between 2 groups, we used Mann-Whitney $U$ tests. Differences between multiple groups were examined by one-way analysis of variance and Tukey tests for post-hoc analysis. We used Kaplan-Meier survival curves and log-rank statistics to analyze the differences between OS rates and DFS rates. All patients with identifying the period of DFS among OS analysis were used for analysis of DFS rate. To adjust clinical stage and age distribution in TCGA database, we used propensity score matching analysis using a multivariable logistic regression model, and one-to-one pair matching was carried out without replacement. Correlations were examined using Spearman's correlation test. Univariate and multivariate analyses for 5-year OS using TCGA database were carried out by Cox proportional hazards regression analyses.

\section{Conclusions}

In this study, our results showed that miR-451a was significantly downregulated in LUSQ tissues. Moreover, we found that this miRNA acted as a tumor suppressor in LUSQ cells and directly regulated KIF2A. Functional analyses showed that KIF2A was a significant gene in LUSQ pathogenesis and that overexpression of KIF2A was involved in the pathogenesis of LUSQ, thereby characterizing KIF2A as an oncogene. Our approach, to identify aberrantly expressed miRNAs and their downstream cancer-related genes, is a groundbreaking strategy to uncover the novel molecular mechanisms mediating the pathogenesis of LUSQ.

Supplementary Materials: The following are available online at http:/ / www.mdpi.com/2072-6694/11/2/258/s1, Figure S1: Kaplan-Meier analysis of miR-451a expression among LUSQ patients with adjusting clinical stage and age distribution, Figure S2: Clinical significance of expression of miR-451a, miR-144-3p, and miR-144-5p in the patients with LUSQ, Figure S3: Kaplan-Meier analyses of miR-451a and KIF2A expression among other types of cancers, Figure S4: Flowchart illustration of the strategy for identification of target genes of miR-451a, Figure S5: Kaplan-Meier analyses of KIF2A expression among LUSQ patients with adjusting clinical stage and age distribution, Figure S6: Correlation between miR-451a and KIF2A expression in LUSQ patients, Figure S7: Flowchart illustration of the strategy for identification of KIF2A-mediated downstream pathways.

Author Contributions: Conceptualization, A.U., N.S. and H.I.; methodology, N.S.; validation, S.M., H.S. and T.K.; formal analysis, A.U. and T.K.; investigation, N.S. and K.M.; resources, N.S., K.M., Y.Y., N.K., T.S. and H.I.; writing-original draft preparation, A.U. and N.S.; writing—review and editing, N.S., K.M., Y.Y., S.M., H.S., T.K. and T.S.; visualization, A.U. and T.K.; supervision, N.S.; funding acquisition, N.S., T.K. and H.I.

Funding: This research was funded by KAKENHI grants, 18K09338 and 17K09660.

Conflicts of Interest: The authors declare no conflict of interest.

\section{References}

1. Fitzmaurice, C.; Akinyemiju, T.F.; Al Lami, F.H.; Alam, T.; Alizadeh-Navaei, R.; Allen, C.; Alsharif, U.; Alvis-Guzman, N.; Amini, E.; Anderson, B.O.; et al. Global, Regional, and National Cancer Incidence, Mortality, Years of Life Lost, Years Lived with Disability, and Disability-Adjusted Life-Years for 29 Cancer Groups, 1990 to 2016: A Systematic Analysis for the Global Burden of Disease Study. JAMA Oncol. 2018, 4, 1553-1568.

2. Travis, W.D. Pathology of lung cancer. Clin. Chest Med. 2011, 32, 669-692. [CrossRef]

3. Zhou, C.; Wu, Y.L.; Chen, G.; Feng, J.; Liu, X.Q.; Wang, C.; Zhang, S.; Wang, J.; Zhou, S.; Ren, S.; et al. Final overall survival results from a randomised, phase III study of erlotinib versus chemotherapy as first-line treatment of EGFR mutation-positive advanced non-small-cell lung cancer (OPTIMAL, CTONG-0802). Ann. Oncol. 2015, 26, 1877-1883. [CrossRef] [PubMed]

4. Soria, J.C.; Ohe, Y.; Vansteenkiste, J.; Reungwetwattana, T.; Chewaskulyong, B.; Lee, K.H.; Dechaphunkul, A.; Imamura, F.; Nogami, N.; Kurata, T.; et al. Osimertinib in Untreated EGFR-Mutated Advanced Non-Small-Cell Lung Cancer. N. Engl. J. Med. 2018, 378, 113-125. [CrossRef] [PubMed] 
5. Peters, S.; Camidge, D.R.; Shaw, A.T.; Gadgeel, S.; Ahn, J.S.; Kim, D.W.; Ou, S.I.; Perol, M.; Dziadziuszko, R.; Rosell, R.; et al. Alectinib versus Crizotinib in Untreated ALK-Positive Non-Small-Cell Lung Cancer. N. Engl. J. Med. 2017, 377, 829-838. [CrossRef] [PubMed]

6. Reck, M.; Rodriguez-Abreu, D.; Robinson, A.G.; Hui, R.; Csoszi, T.; Fulop, A.; Gottfried, M.; Peled, N.; Tafreshi, A.; Cuffe, S.; et al. Pembrolizumab versus Chemotherapy for PD-L1-Positive non-small-cell lung cancer. N. Engl. J. Med. 2016, 375, 1823-1833. [CrossRef] [PubMed]

7. Gandara, D.R.; Hammerman, P.S.; Sos, M.L.; Lara, P.N., Jr.; Hirsch, F.R. Squamous cell lung cancer: From tumor genomics to cancer therapeutics. Clin. Cancer Res. 2015, 21, 2236-2243. [CrossRef] [PubMed]

8. Little, A.G.; Gay, E.G.; Gaspar, L.E.; Stewart, A.K. National survey of non-small cell lung cancer in the United States: Epidemiology, pathology and patterns of care. Lung Cancer 2007, 57, 253-260. [CrossRef]

9. Bartel, D.P. MicroRNAs: Genomics, biogenesis, mechanism, and function. Cell 2004, 116, 281-297. [CrossRef]

10. Bartel, D.P. MicroRNAs: Target recognition and regulatory functions. Cell 2009, 136, 215-233. [CrossRef]

11. Baranwal, S.; Alahari, S.K. miRNA control of tumor cell invasion and metastasis. Int. J. Cancer 2010, 126, 1283-1290. [CrossRef] [PubMed]

12. Rupaimoole, R.; Slack, F.J. MicroRNA therapeutics: Towards a new era for the management of cancer and other diseases. Nat. Rev. Drug Discov. 2017, 16, 203-222. [CrossRef] [PubMed]

13. Lin, S.; Gregory, R.I. MicroRNA biogenesis pathways in cancer. Nat. Rev. Cancer 2015, 15, 321. [CrossRef] [PubMed]

14. Mizuno, K.; Mataki, H.; Seki, N.; Kumamoto, T.; Kamikawaji, K.; Inoue, H. MicroRNAs in non-small cell lung cancer and idiopathic pulmonary fibrosis. J. Hum. Genet. 2017, 62, 57-65. [CrossRef] [PubMed]

15. Mataki, H.; Seki, N.; Mizuno, K.; Nohata, N.; Kamikawaji, K.; Kumamoto, T.; Koshizuka, K.; Goto, Y.; Inoue, H. Dual-strand tumor-suppressor microRNA-145 (miR-145-5p and miR-145-3p) coordinately targeted MTDH in lung squamous cell carcinoma. Oncotarget 2016, 7, 72084-72098. [CrossRef] [PubMed]

16. Suetsugu, T.; Koshizuka, K.; Seki, N.; Mizuno, K.; Okato, A.; Arai, T.; Misono, S.; Uchida, A.; Kumamoto, T.; Inoue, $\mathrm{H}$. Downregulation of matrix metalloproteinase 14 by the antitumor miRNA, miR-150-5p, inhibits the aggressiveness of lung squamous cell carcinoma cells. Int. J. Oncol. 2018, 52, 913-924. [CrossRef]

17. Mizuno, K.; Seki, N.; Mataki, H.; Matsushita, R.; Kamikawaji, K.; Kumamoto, T.; Takagi, K.; Goto, Y.; Nishikawa, R.; Kato, M.; et al. Tumor-suppressive microRNA-29 family inhibits cancer cell migration and invasion directly targeting LOXL2 in lung squamous cell carcinoma. Int. J. Oncol. 2016, 48, 450-460. [CrossRef]

18. Kumamoto, T.; Seki, N.; Mataki, H.; Mizuno, K.; Kamikawaji, K.; Samukawa, T.; Koshizuka, K.; Goto, Y.; Inoue, H. Regulation of TPD52 by antitumor microRNA-218 suppresses cancer cell migration and invasion in lung squamous cell carcinoma. Int. J. Oncol. 2016, 49, 1870-1880. [CrossRef]

19. Uchida, A.; Seki, N.; Mizuno, K.; Misono, S.; Yamada, Y.; Kikkawa, N.; Sanada, H.; Kumamoto, T.; Suetsugu, T.; Inoue, H. Involvement of dual-strand of the miR-144 duplex and their targets in the pathogenesis of lung squamous cell carcinoma. Cancer Sci. 2018. [CrossRef]

20. Mataki, H.; Enokida, H.; Chiyomaru, T.; Mizuno, K.; Matsushita, R.; Goto, Y.; Nishikawa, R.; Higashimoto, I.; Samukawa, T.; Nakagawa, M.; et al. Downregulation of the microRNA-1/133a cluster enhances cancer cell migration and invasion in lung-squamous cell carcinoma via regulation of Coronin1C. J. Hum. Genet. 2015, 60, 53-61. [CrossRef]

21. Kojima, S.; Chiyomaru, T.; Kawakami, K.; Yoshino, H.; Enokida, H.; Nohata, N.; Fuse, M.; Ichikawa, T.; Naya, Y.; Nakagawa, M.; et al. Tumour suppressors miR-1 and miR-133a target the oncogenic function of purine nucleoside phosphorylase (PNP) in prostate cancer. Br. J. Cancer 2012, 106, 405-413. [CrossRef]

22. Nohata, N.; Hanazawa, T.; Kikkawa, N.; Sakurai, D.; Sasaki, K.; Chiyomaru, T.; Kawakami, K.; Yoshino, H.; Enokida, H.; Nakagawa, M.; et al. Identification of novel molecular targets regulated by tumor suppressive miR-1/miR-133a in maxillary sinus squamous cell carcinoma. Int. J. Oncol. 2011, 39, 1099-1107.

23. Nohata, N.; Hanazawa, T.; Enokida, H.; Seki, N. microRNA-1/133a and microRNA-206/133b clusters: Dysregulation and functional roles in human cancers. Oncotarget 2012, 3, 9-21. [CrossRef] [PubMed]

24. Goto, Y.; Kojima, S.; Nishikawa, R.; Enokida, H.; Chiyomaru, T.; Kinoshita, T.; Nakagawa, M.; Naya, Y.; Ichikawa, T.; Seki, N. The microRNA-23b/27b/24-1 cluster is a disease progression marker and tumor suppressor in prostate cancer. Oncotarget 2014, 5, 7748-7759. [CrossRef] 
25. Yoshino, H.; Enokida, H.; Itesako, T.; Kojima, S.; Kinoshita, T.; Tatarano, S.; Chiyomaru, T.; Nakagawa, M.; Seki, N. Tumor-suppressive microRNA-143/145 cluster targets hexokinase-2 in renal cell carcinoma. Cancer Sci. 2013, 104, 1567-1574. [CrossRef] [PubMed]

26. Kojima, S.; Enokida, H.; Yoshino, H.; Itesako, T.; Chiyomaru, T.; Kinoshita, T.; Fuse, M.; Nishikawa, R.; Goto, Y.; Naya, Y.; et al. The tumor-suppressive microRNA-143/145 cluster inhibits cell migration and invasion by targeting GOLM1 in prostate cancer. J. Hum. Genet. 2014, 59, 78-87. [CrossRef] [PubMed]

27. Goto, Y.; Kojima, S.; Nishikawa, R.; Kurozumi, A.; Kato, M.; Enokida, H.; Matsushita, R.; Yamazaki, K.; Ishida, Y.; Nakagawa, M.; et al. MicroRNA expression signature of castration-resistant prostate cancer: The microRNA-221/222 cluster functions as a tumour suppressor and disease progression marker. Br. J. Cancer 2015, 113, 1055-1065. [CrossRef]

28. Fukumoto, I.; Kinoshita, T.; Hanazawa, T.; Kikkawa, N.; Chiyomaru, T.; Enokida, H.; Yamamoto, N.; Goto, Y.; Nishikawa, R.; Nakagawa, M.; et al. Identification of tumour suppressive microRNA-451a in hypopharyngeal squamous cell carcinoma based on microRNA expression signature. Br. J. Cancer 2014, 111, 386-394. [CrossRef]

29. Yamada, Y.; Arai, T.; Kojima, S.; Sugawara, S.; Kato, M.; Okato, A.; Yamazaki, K.; Naya, Y.; Ichikawa, T.; Seki, N. Regulation of antitumor miR-144-5p targets oncogenes: Direct regulation of syndecan-3 and its clinical significance. Cancer Sci. 2018. [CrossRef]

30. Yamada, Y.; Arai, T.; Sugawara, S.; Okato, A.; Kato, M.; Kojima, S.; Yamazaki, K.; Naya, Y.; Ichikawa, T.; Seki, N. Impact of novel oncogenic pathways regulated by antitumor miR-451a in renal cell carcinoma. Cancer Sci. 2018, 109, 1239-1253. [CrossRef]

31. Matsushita, R.; Seki, N.; Chiyomaru, T.; Inoguchi, S.; Ishihara, T.; Goto, Y.; Nishikawa, R.; Mataki, H.; Tatarano, S.; Itesako, T.; et al. Tumour-suppressive microRNA-144-5p directly targets CCNE1/2 as potential prognostic markers in bladder cancer. Br. J. Cancer 2015, 113, 282-289. [CrossRef]

32. Bandres, E.; Bitarte, N.; Arias, F.; Agorreta, J.; Fortes, P.; Agirre, X.; Zarate, R.; Diaz-Gonzalez, J.A.; Ramirez, N.; Sola, J.J.; et al. microRNA-451 regulates macrophage migration inhibitory factor production and proliferation of gastrointestinal cancer cells. Clin. Cancer Res. 2009, 15, 2281-2290. [CrossRef]

33. Kim, Y.; Kang, H.; Powathil, G.; Kim, H.; Trucu, D.; Lee, W.; Lawler, S.; Chaplain, M. Role of extracellular matrix and microenvironment in regulation of tumor growth and LAR-mediated invasion in glioblastoma. PLoS ONE 2018, 13, e0204865. [CrossRef]

34. Liu, N.; Jiang, N.; Guo, R.; Jiang, W.; He, Q.M.; Xu, Y.F.; Li, Y.Q.; Tang, L.L.; Mao, Y.P.; Sun, Y.; et al. MiR-451 inhibits cell growth and invasion by targeting MIF and is associated with survival in nasopharyngeal carcinoma. Mol. Cancer 2013, 12, 123. [CrossRef]

35. Chen, D.Q.; Yu, C.; Zhang, X.F.; Liu, Z.F.; Wang, R.; Jiang, M.; Chen, H.; Yan, F.; Tao, M.; Chen, L.B.; et al. HDAC3-mediated silencing of miR-451 decreases chemosensitivity of patients with metastatic castration-resistant prostate cancer by targeting NEDD9. Ther. Adv. Med. Oncol. 2018, 10, 1758835918783132. [CrossRef]

36. Wang, R.; Wang, Z.X.; Yang, J.S.; Pan, X.; De, W.; Chen, L.B. MicroRNA-451 functions as a tumor suppressor in human non-small cell lung cancer by targeting Ras-related protein 14 (RAB14). Oncogene 2011, 30, $2644-2658$. [CrossRef]

37. Goto, A.; Tanaka, M.; Yoshida, M.; Umakoshi, M.; Nanjo, H.; Shiraishi, K.; Saito, M.; Kohno, T.; Kuriyama, S.; Konno, H.; et al. The low expression of miR-451 predicts a worse prognosis in non-small cell lung cancer cases. PLoS ONE 2017, 12, e0181270. [CrossRef]

38. Chang, C.; Liu, J.; He, W.; Qu, M.; Huang, X.; Deng, Y.; Shen, L.; Zhao, X.; Guo, H.; Jiang, J.; et al. A regulatory circuit HP1gamma/miR-451a/c-Myc promotes prostate cancer progression. Oncogene 2018, 37, 415-426. [CrossRef]

39. Desai, A.; Verma, S.; Mitchison, T.J.; Walczak, C.E. Kin I kinesins are microtubule-destabilizing enzymes. Cell 1999, 96, 69-78. [CrossRef]

40. Ganem, N.J.; Compton, D.A. The KinI kinesin Kif2a is required for bipolar spindle assembly through a functional relationship with MCAK. J. Cell Biol. 2004, 166, 473-478. [CrossRef]

41. Ems-McClung, S.C.; Walczak, C.E. Kinesin-13s in mitosis: Key players in the spatial and temporal organization of spindle microtubules. Semin. Cell Dev. Biol. 2010, 21, 276-282. [CrossRef] [PubMed] 
42. Wang, J.; Ma, S.; Ma, R.; Qu, X.; Liu, W.; Lv, C.; Zhao, S.; Gong, Y. KIF2A silencing inhibits the proliferation and migration of breast cancer cells and correlates with unfavorable prognosis in breast cancer. BMC Cancer 2014, 14, 461. [CrossRef] [PubMed]

43. Wang, C.Q.; Qu, X.; Zhang, X.Y.; Zhou, C.J.; Liu, G.X.; Dong, Z.Q.; Wei, F.C.; Sun, S.Z. Overexpression of Kif2a promotes the progression and metastasis of squamous cell carcinoma of the oral tongue. Oral Oncol. 2010, 46, 65-69. [CrossRef] [PubMed]

44. Fan, X.; Wang, X.; Zhu, H.; Wang, W.; Zhang, S.; Wang, Z. KIF2A overexpression and its association with clinicopathologic characteristics and unfavorable prognosis in colorectal cancer. Tumour Biol. 2015, 36, 8895-8902. [CrossRef] [PubMed]

45. Sheng, N.; Xu, Y.Z.; Xi, Q.H.; Jiang, H.Y.; Wang, C.Y.; Zhang, Y.; Ye, Q. Overexpression of KIF2A is Suppressed by miR-206 and Associated with Poor Prognosis in Ovarian Cancer. Cell. Physiol. Biochem. 2018, 50, 810-822. [CrossRef]

46. Xie, T.; Li, X.; Ye, F.; Lu, C.; Huang, H.; Wang, F.; Cao, X.; Zhong, C. High KIF2A expression promotes proliferation, migration and predicts poor prognosis in lung adenocarcinoma. Biochem. Biophys. Res. Commun. 2018, 497, 65-72. [CrossRef] [PubMed]

47. Wu, W.; Wang, X.; Shan, C.; Li, Y.; Li, F. Minichromosome maintenance protein 2 correlates with the malignant status and regulates proliferation and cell cycle in lung squamous cell carcinoma. Onco. Targets Ther. 2018, 11, 5025-5034. [CrossRef] [PubMed]

48. Kikuchi, J.; Kinoshita, I.; Shimizu, Y.; Kikuchi, E.; Takeda, K.; Aburatani, H.; Oizumi, S.; Konishi, J.; Kaga, K.; Matsuno, Y.; et al. Minichromosome maintenance (MCM) protein 4 as a marker for proliferation and its clinical and clinicopathological significance in non-small cell lung cancer. Lung Cancer 2011, 72, $229-237$. [CrossRef] [PubMed]

49. Mirsadraee, S.; Oswal, D.; Alizadeh, Y.; Caulo, A.; van Beek, E., Jr. The 7th lung cancer TNM classification and staging system: Review of the changes and implications. World J. Radiol. 2012, 4, 128-134. [CrossRef]

50. Mataki, H.; Seki, N.; Chiyomaru, T.; Enokida, H.; Goto, Y.; Kumamoto, T.; Machida, K.; Mizuno, K.; Nakagawa, M.; Inoue, H. Tumor-suppressive microRNA-206 as a dual inhibitor of MET and EGFR oncogenic signaling in lung squamous cell carcinoma. Int. J. Oncol. 2015, 46, 1039-1050. [CrossRef]

51. Mizuno, K.; Mataki, H.; Arai, T.; Okato, A.; Kamikawaji, K.; Kumamoto, T.; Hiraki, T.; Hatanaka, K.; Inoue, H.; Seki, N. The microRNA expression signature of small cell lung cancer: Tumor suppressors of miR-27a-5p and miR-34b-3p and their targeted oncogenes. J. Hum. Genet. 2017, 62, 671-678. [CrossRef] [PubMed]

52. Arai, T.; Kojima, S.; Yamada, Y.; Sugawara, S.; Kato, M.; Yamazaki, K.; Naya, Y.; Ichikawa, T.; Seki, N. Pirin: A potential novel therapeutic target for castration-resistant prostate cancer regulated by miR-455-5p. Mol. Oncol. 2018. [CrossRef] [PubMed]

53. Matsushita, R.; Yoshino, H.; Enokida, H.; Goto, Y.; Miyamoto, K.; Yonemori, M.; Inoguchi, S.; Nakagawa, M.; Seki, N. Regulation of UHRF1 by dual-strand tumor-suppressor microRNA-145 (miR-145-5p and miR-145-3p): Inhibition of bladder cancer cell aggressiveness. Oncotarget 2016, 7, 28460-28487. [CrossRef] [PubMed]

54. Cerami, E.; Gao, J.; Dogrusoz, U.; Gross, B.E.; Sumer, S.O.; Aksoy, B.A.; Jacobsen, A.; Byrne, C.J.; Heuer, M.L.; Larsson, E.; et al. The cBio cancer genomics portal: An open platform for exploring multidimensional cancer genomics data. Cancer Discov. 2012, 2, 401-404. [CrossRef] [PubMed]

55. Misono, S.; Seki, N.; Mizuno, K.; Yamada, Y.; Uchida, A.; Arai, T.; Kumamoto, T.; Sanada, H.; Suetsugu, T.; Inoue, H. Dual strands of the miR-145 duplex (miR-145-5p and miR-145-3p) regulate oncogenes in lung adenocarcinoma pathogenesis. J. Hum. Genet. 2018. [CrossRef] [PubMed]

56. Yamada, Y.; Sugawara, S.; Arai, T.; Kojima, S.; Kato, M.; Okato, A.; Yamazaki, K.; Naya, Y.; Ichikawa, T.; Seki, N. Molecular pathogenesis of renal cell carcinoma: Impact of the anti-tumor miR-29 family on gene regulation. Int. J. Urol. 2018, 25, 953-965. [CrossRef] [PubMed]

57. Koshizuka, K.; Nohata, N.; Hanazawa, T.; Kikkawa, N.; Arai, T.; Okato, A.; Fukumoto, I.; Katada, K.; Okamoto, Y.; Seki, N. Deep sequencing-based microRNA expression signatures in head and neck squamous cell carcinoma: Dual strands of pre-miR-150 as antitumor miRNAs. Oncotarget 2017, 8, 30288-30304. [CrossRef] [PubMed]

(C) 2019 by the authors. Licensee MDPI, Basel, Switzerland. This article is an open access article distributed under the terms and conditions of the Creative Commons Attribution (CC BY) license (http://creativecommons.org/licenses/by/4.0/). 